Sybiriakin la, Balazh M. Modern views on the application of physical therapy measures in persons with stroke. Theory and Methods of Physical education and sports. 2020; 1: 93-98 DOI: $10.32652 /$ tmfvs.2020.1.93-98
Сибірякін Я, Балаж М. Сучасні погляди на застосування заходів фрізичної терапії в осіб з інсультом.

Теорія і методика фрізичного виховання і спорту. 2020; 1: 93-98 DOI: $10.32652 /$ tmfvs.2020.1.93-98

\title{
СУЧАСНІ ПОГЛЯДИ НА ЗАСТОСУВАННЯ ЗАХОДІВ ФІЗИЧНОї ТЕРАПІї В ОСІБ 3 ІНСУЛЬТОМ
}

\section{Ярослав Сибірякін, Марія Балаж}

Національний університет фізичного виховання і спорту України, Київ, Україна

\begin{abstract}
Анотація. Збільшення захворюваності та смертності у світі внаслідок інсульту веде до необхідності розвитку реабілітації постінсультних хворих. Тому різні профільні асоціації у розвинутих країнах розробляють клінічні настанови з реабілітації хворих після інсульту, які базуються на засадах доказової медицини. Мета. Розглянути сучасні підходи до застосування заходів фрізичної терапії в осіб після інсульту. Методи. Теоретичний аналіз і узагальнення сучасних науково-методичних літературних даних про застосування заходів фрізичної терапії в осіб з інсультом. Результати. Однією з основних причин інвалідизації, смертності населення й тривалої тимчасової втрати працездатності $є$ наслідки цереброваскулярних ушкоджень головного мозку. Сучасні погляди на відновлення пацієнтів після перенесеного інсульту будуються на концепції Міжнародної класифікації функціонування (МКФ). Згідно з рекомендаціями сучасних клінічних настанов, реабілітація пацієнтів 3 інсультом повинна починатися з перших діб перебування пацієнта у лікувальному закладі. Це має бути спеціалізоване інсультне відділення з мультидисциплінарною командою. Надання медичної допомоги на засадах доказової медицини знижує смертність та подальшу інвалідизацію у пацієнтів з інсультом. До методів втручання з доведеною ефективністю при інсульті належать рання вертикалізація пацієнта, вправи на рівновагу, виконання аеробних вправ на витривалість. Вважається, що втручання, спрямовані на зменшення спастичності не повинні рутинно надаватись пацієнтам з легким та середнім ступенями прояву спастики. Якщо прояви спастичності заважають здійснювати діяльність та особисту гігієну, тоді слід скористатися доведеними засобами для її зменшення. Аналіз робіт вітчизняних учених показав, що для реабілітації осіб, які перенесли інсульт, пропонують використовувати методи з недоведеною ефективністю, такі як масаж, акупунктура та рефрлексотерапія, теплові процедури, кріотерапія, фітотерапія, магнітотерапія, що не відповідає міжнародним настановам. Реабілітація пацієнтів після перенесеного інсульту досить актуальна і постійно досліджується. Постійно пропонуються нові засоби фрізичної терапії. Вони аналізуються профільними установами та зводяться у систематичні огляди, на базі яких вже можна зробити висновок про їх ефрективність. Для того щоб орієнтуватись у сучасних тенденціях реабілітації, потрібно постійно стежити за міжнародними настановами, які майже кожен рік оновлюються.
\end{abstract}

Ключові слова: фрізична терапія, реабілітація, настанови, інсульт, мозок.

\section{Iaroslav Sybiriakin, Maria Balazh MODERN VIEWS ON THE APPLICATION OF PHYSICAL THERAPY MEASURES IN PERSONS WITH STROKE}

\begin{abstract}
The increase in morbidity and mortality in the world due to stroke necessitates the development of rehabilitation of post-stroke patients. Therefore, various specialized associations in developed countries are developing clinical guidelines for the rehabilitation of patients after stroke, which are based on the principles of evidence-based medicine. Objective. Consider modern approaches to the use of physical therapy in individuals after stroke. Methods. Theoretical analysis and generalization of modern scientific and methodological literature data on the use of physical therapy in people with stroke. Results. One of the main causes of disablement, mortality and long-term disability is the consequences of cerebrovascular injuries. Modern views on the recovery of patients after stroke are based on the concept of the International Classification of Functioning (ICF). According to the recommendations of modern clinical guidelines, rehabilitation of patients with stroke should begin from the first days of the patient's stay in the hospital. It should be a specialized stroke unit with a multidisciplinary team. Provision of evidencebased care reduces mortality and subsequent disability in stroke patients. Methods of intervention with proven effectiveness in stroke include early verticalization of the patient, balance exercises, performing aerobic endurance exercises. It is believed that interventions aimed at reducing spasticity should not be routinely provided to patients with mild to moderate spasticity. If the manifestations of spasticity interfere with exercise and personal hygiene, then you should use proven means to reduce it. Analysis of the works of domestic scientists has shown that for the rehabilitation of stroke victims, it is proposed to use methods with unproven effectiveness, such as massage, acupuncture and reflexology, thermal treatments, cryotherapy, herbal medicine, magnetic therapy, which does not comply with international guidelines. Rehabilitation of patients after stroke is quite relevant and is being studied constantly. New means of physical therapy are constantly offered. They are analyzed by specialized institutions and reduced to systematic reviews, on the basis of which it is already possible to draw a conclusion about their effectiveness. In or-
\end{abstract}


der to be familiar with current trends in rehabilitation, it is necessary to constantly follow the international guidelines, which are updated almost every year.

Keywords: physical therapy, rehabilitation, guidelines, stroke, brain.

Вступ. Гостре порушення мозкового кровообігу, також відоме як інсульт, належить до найбільш тяжких форм цереброваскулярних захворювань. Серед усіх видів інсультів домінують ішемічні ураження мозку, які становлять 70-85\%, геморагічні інсульти зустрічаються у 20-25 \% випадків, а нетравматичні субарахноїдальні крововиливи $-5 \%$.

Проблема інсульту досить актуальна і соціально значуща для України. Щорічно в світі інсульт переносять майже шість мільйонів осіб (за даними ВООЗ, у розвинутих країнах світу реєструють від 100 до 200 інсультів на кожні 100 тис. населення), щороку в Україні від 100 до 125 тис. населення вперше переносять інсульт, тобто захворюваність становить 280-300 випадків на 100 тис. населення, що перевищує середній показник захворюваності в економічно розвинених країнах Свропи. Останні дані свідчать, що в Україні від наслідків інсульту померло 79 тис. населення. У найближче десятиліття експерти ВООЗ прогнозують подальше зростання кількості мозкових інсультів. Відповідно до прогнозів, у 2020 р. захворюваність на інсульт зросте на 25 \%, що обумовлено старінням населення планети і ростом поширеності в популяції таких факторів ризику, як артеріальна гіпертензія, ожиріння, хвороби серця, цукровий діабет, куріння тощо [6, 22].

Збільшення захворюваності та смертності у світі внаслідок гострого порушення мозкового кровообігу веде до необхідності розвитку реабілітації постінсультних хворих. Тому різні профільні асоціації у розвинутих країнах розробляють клінічні настанови, які базуються на засадах доказової медицини, аналізуючи багато досліджень та систематичні огляди. Вважається, що цим настановам слід більше довіряти, ніж поодиноким дослідженням, оскільки в них враховують не тільки результати досліджень, а й їх дизайн, якість та конфлікти інтересів. Тому порівняльний аналіз заходів, які застосовують у фізичній терапії в міжнародній практиці та в Україні, ставить багато запитань до доцільності застосування деяких методів реабілітації при інсульті, що вважаються традиційними у вітчизняній практиці.

Роботу виконано відповідно до плану НДР НУФВСУ на 2016-2020 рр. за темою 4.2. «Організаційні та теоретико-методичні основи фізичної реабілітації осіб різних нозологічних, професійних та вікових груп» (номер держреєстрації 0116U001609).

Мета дослідження - розглянути сучасні підходи до застосування заходів фізичної терапії в осіб після інсульту.
Методи дослідження: аналіз та узагальнення даних зарубіжної та вітчизняної наукової та науково-методичної літератури.

Результати дослідження та їх обговорення. За визначенням ВООЗ, інсульт - це клінічний синдром швидкого розвитку ознак фокальної чи глобальної втрати мозкових функцій, що тривають 24 год і більше або призводять до смерті за відсутності несудинних причин [8]. Летальність у хворих з інсультами значною мірою залежить від умов лікування в гострому періоді недуги. Рання тридцятиденна летальність після інсульту становить близько 35 \%, у стаціонарах - $24 \%$, а в осіб, які лікувалися в домашніх умовах, - 43 \% [9].

Однією 3 основних причин інвалідизації, смертності населення й тривалої тимчасової втрати працездатності є наслідки цереброваскулярних ушкоджень головного мозку. Активність та якість повсякденного життя значною мірою можуть погіршуватись через геміплегію, геміпарез, спастичність, синергії, атрофію та порушення чутливості, які впливають на рухову сферу. Порушення у когнітивній сфері включають афазію, апраксію, проблеми з пам'яттю, мисленням, увагою та навчанням, неглект, який порушує усвідомлення половини тіла та простору. Також часто зустрічаються такі порушення, як дефекти полів зору, дисфагія, дизартрія та проблеми 3 контролем за функціями тазових органів. Усе перераховане може легко призвести до депресії та емоційної лабільності.

Сучасні погляди на відновлення пацієнтів після перенесеного інсульту будуються на концепції Міжнародної класифікації функціонування, обмежень життєдіяльності та здоров'я (МКФ), яка впроваджує визначення компонентів здоров'я та наголошує на здоров’ї і функціонуванні, а не на неповносправності [4, 5]. Використовуючи МКФ, формують індивідуальні довгострокові цілі, які визначають кінцеву точку терапії та короткострокові цілі, які допомагають правильно сфокусувати лікування. Цілі ставляться у SMART-форматі i мають бути спрямовані на активність (виконання особою завдання або дії) та участь (залучення особи в життеву ситуацію та суспільну діяльність). Ціль потрібно узгоджувати з пацієнтом або родичами. Доведено, що такий підхід до реабілітації осіб, які перенесли інсульт, сприяє кращим результатам відновлення [16].

Реабілітація пацієнтів 3 інсультом повинна починатися з перших діб перебування їх у лікувальному закладі. Згідно 3 клінічними настановами, це має бути спеціалізоване інсультне відділення, в якому є мультидисциплінарна команда у повному складі. Це зменшує летальність на 20 \% та інвалідність на 30 \%, а також витрати, пов'язані 3 доглядом за пацієнтом на всіх етапах надання ме- 
дичної допомоги, яка на засадах доказової медицини, знижує смертність та подальшу інвалідизацію у пацієнтів з гострим порушенням мозкового кровообігу [8, 12, 17, 19].

Усі пацієнти з інсультом повинні отримувати реабілітацію якомога раніше (не плутати 3 дуже ранньою мобілізацією - 24 год після інсульту), коли вони медично стабільні та можуть брати участь в активній реабілітації. Рання мобілізація після інсульту (48 год після початку інсульту) має на меті зменшити ризик виникнення ускладнень, включаючи тромбоз глибоких вен, пролежні, біль у плечі, пневмонію та легеневу емболію [1]. Потенційні переваги дуже ранньої мобілізації були вивчені в кількох рандомізованих контрольованих дослідженнях, що мали неоднозначні результати. Вони свідчать про шкоду та еквівалентність між групами втручання та контрольними групами. Незважаючи на те що результати недавнього Кохрейнівського огляду показали, що дуже рання мобілізація протягом 24-48 год сприяє значному зменшенню тривалості перебування в лікарні та більш високим балам за індексом Бартела, шанси смерті або поганий результат не зменшувалися.

Як тільки є дозвіл на вертикалізацію пацієнта, рекомендується одразу починати вправи на рівновагу. Терапевту слід враховувати як довільний, так і реакційний контроль балансу в межах своєї оцінки та лікування [13, 15, 18, 21].

Для покращення балансу після інсульту слід розглядати такі методи:

- тренування тулуба, тренування балансу в положенні сидячи. Дотягування випрямленою рукою у положенні сидячи, під контролем (якщо потрібно, то з допомогою);

- тренування вставання (переходу з положення сидячи в положення стоячи);

- орієнтоване тренування зі зворотним зв'язком;

- тренування рівноваги у поєднанні 3 віртуальною реальністю (в пізній фазі інсульту);

- використання нестійких поверхонь і балансуючих дощок;

- тренування на велосипеді;

- тренування рівноваги у басейні.

Розглядаючи порушення ходи, можна виділити ряд рекомендацій до реабілітації, які мають сукупність доказів, котрим можна довіряти, для впровадження їх у практичну діяльність:

- усі пацієнти з порушенням ходи повинні брати участь у інтенсивних, постійно прогресуючих, орієнтованих на завдання тренуваннях;

- силові тренування слід проводити особам із легким та помірним порушенням функції нижньої кінцівки як у підгострій, так і у хронічній фазі відновлення. Вони не впливають на тонус або біль;

- тренування ходи на біговій доріжці (з підтриманням ваги тіла або без) слід використовувати для підвищення швидкості ходьби та дистанції - як доповнення до тренувань ходи на землі, або коли такі тренування недоступні;
- електромеханічні (роботизовані) пристрої для навчання ходи можуть розглядатися для пацієнтів, які не можуть практикувати звичайну ходьбу. Їх не слід застосовувати замість звичайної терапії ходи;

- для поліпшення сили та функціональності ходьби у відібраних пацієнтів можна використовувати функціональну електростимуляцію, але ефекти можуть не бути стійкими;

- біологічно зворотний зв'язок у вигляді зорових та / або слухових сигналів для вказівки на нерівномірно перенесену вагу тіла можна використовувати для посилення тренувань ходи та покращення функціонального відновлення;

- ортези для надп'ятково-гомілкового суглоба слід застосовувати відібраним пацієнтам тільки після аналізу ходи, виявлення відхилень, належної оцінки та подальшого контролю для перевірки його ефективності;

- необхідність у допоміжних засобах для ходьби, інвалідних візках та інших допоміжних пристроях слід оцінювати індивідуально;

- призначення та / або придбання допоміжного пристрою має базуватися на прогнозуванні довгострокової потреби;

- після надання допоміжного пристрою, стан пацієнта слід переоцінити, щоб визначити, чи відбулись бажані зміни, чи ні (в такому випадку пристрій слід вилучити) [13, 15, 18, 21].

Cnacmuчнісmь. Нині вважається, що втручання, спрямовані на зменшення спастичності, крім ранньої комплексної програми терапії (позиціонування, вправи на підтримання амплітуди руху, на зміцнення м'язів-антагоністів, розтягнення), не повинні рутинно надаватись пацієнтам, в яких легкий та середній ступені прояву спастики (тобто, якщо спастичність не заважає у повсякденній діяльності або особистій гігієні). Але якщо прояви спастичності мають важкий ступінь та заважають здійснювати діяльність та особисту гігієну, тоді слід скористатися доведеними засобами для її зменшення. Одним з небагатьох є терапія ботулінічним токсином типу А. Вона має застосовуватись у поєднанні з фізичною терапією та включати постановку чітких цілей. Також є докази, хоча і менші, що можна використовувати електростимуляцію або електроміографію 3 біологічним зворотним зв'язком [13, 21].

Кардіореспіраторна система. Як тільки вітальні функції пацієнта стають стабільними, слід провести оцінку на можливість виконувати аеробні вправи на витривалість. Слід вивчити історію хвороби та провести фізичне обстеження для виявлення чинників, які вимагають особливої уваги, або є протипоказанням для аеробних вправ. Для пацієнтів із відомою історією серцево-судинних захворювань слід проводити навантажувальний тест з електрокардіограмою та спостереження за артеріальним тиском і суб'єктивними симптомами. Якщо цільова інтенсивність за- 
планованої програми невелика (тобто < 40-45 \% прогнозованого резерву серцевого ритму), клінічний субмаксимальний тест (наприклад, шестихвилинний тест на прогулянку) може бути достатнім для оцінки готовності до аеробних тренувань [21].

Індивідуально підібрані аеробні тренування 3 участю великих м'язових груп повинні бути включені в комплексну програму реабілітації інсульту для підвищення серцево-судинної витривалості та когнітивних функцій. Щоб досягти тренувального ефекту, пацієнти повинні брати участь у аеробних вправах не рідше трьох разів на тиждень протягом мінімум восьми тижнів, прогресуючи (на скільки це можливо) від 20 хв і більше за сеанс, виключаючи розминку та заминку. Під час тренування слід контролювати частоту серцевих скорочень та артеріальний тиск для безпеки та досягнення цільової інтенсивності вправ [20].

Проаналізувавши роботи вітчизняних авторів можна помітити, що у реабілітації осіб, які перенесли інсульт, пропонують використовувати такі засоби, як масаж, акупунктуру та рефлексотерапію, теплові процедури (озокерит, парафін), кріо- терапію, фітотерапію, магнітотерапію. Однак, всі ці засоби не довели свою ефективність, та не були включені у клінічні настанови. Щодо акупунктури, то є рекомендації, які говорять, що її не слід застосовувати для лікування спастичності в рутинній практиці, окрім як в рамках дослідження [2, 3, 7, 10, 11, 14].

Висновки. Реабілітація пацієнтів після перенесеного інсульту досить актуальна і постійно досліджується. Постійно пропонуються нові засоби фізичної терапії. Вони аналізуються профільними установами та зводяться у систематичні огляди, на базі яких вже можна зробити висновок про їх ефективність. Для того, щоб орієнтуватись у сучасних тенденціях реабілітації, потрібно постійно стежити за міжнародними настановами, які майже кожен рік оновлюються.

Перспективи подальших досліджень передбачають проведення наукових розвідок з метою подальшого розвитку поглядів на відновлення функціональної активності хворих після ГПМК.

Конфлікт інтересів. Автори заявляють, що відсутній будь-який конфлікт інтересів.

\section{Література}

1. Віничук СМ, Фартушна ОЄ. Рання реабілітація після гострих ішемічних порушень мозкового кровообігу. Міжнародний неврологічний журнал. 2016; 8: 34-9.

2. Іванська ОВ, Калашнік ІК. Фізична терапія, як засіб відновлення хворих на ішемічний інсульт. Вісник Запорізького національного університету. Фізичне виховання та спорт. 2017; 2: 42-6.

3. Клапчук ВВ, Миренко АО, Пономарьов ДА. Комплексна фрізична реабілітація людей похилого віку у ранні терміни після інсульту. Спортивна медицина і фрізична реабілітація. 2019; 1: 113-8.

4. Международная классификация функционирования, ограничений жизнедеятельности и здоровья: МКФ. Всемирная Организация Здравоохранения, 2001. 342 с.

5. Международная классификация функционирования, ограничений жизнедеятельности и здоровья: МКФ, краткая версия. Всемирная Организация Здравоохранения. Санкт-Петербург. 2003. 228 с.

6. Мицкан БМ. Інсульт: різновиди, фактори ризику, фізична реабілітація. Фізичне виховання, спорт і культура здоров'я у сучасному суспільстві. 2012; 3(19): 295-302.

7. Молчанова ЕЕ. Опыт сочетанного применения динамической электронейростимуляции и акупунктуры в остром периоде ишемического инсульта. ConsiliumMedicum. 2017; 19(2-1): 82-85.

8. Наказ Міністерства охорони здоров'я України 17.04.2014 № 275 Уніфікований клінічний протокол екстреної, первинної, вторинної (спеціалізованої), третинної (високоспеціалізованої) медичної допомоги та медичної реабілітації. Геморагічний інсульт (внутрішньомозкова гематома, аневризмальний субарахноїдальний крововилив).

9. Олейник ИВ. Состояние и перспективы решения мозкових инсультов, их социальномедицинских последствий (обзор литературы). Вісник морфології. 2010; 16(3): 734-7.

10. Худецький ЮЮ, Хоменко ЄС, Антонова-Рафрі ЮВ. Особливості фрізичної реабілітації людей похилого віку із неврологічними захворюваннями. Молодий вчений. 2018; 10 (1): 155-7.

11. Юхимчук ХВ. Реабілітація хворих з інсультом. Медсестринство. 2018; 3: 23-6.

12. Belagaje Samir R. Stroke rehabilitation. Continuum: Life long Learning in Neurology 23.1, CerebrovascularDisease. 2017. 238-53.

13. Clinical Guidelines for Stroke Management 2017. Available from: https://informme.org.au/en/Guidelines/ Clinical-Guidelines-for-Stroke-Management-2017.

14. Dovguy I, Svyrydova N. Rehabilitation of patients who suffered an ischemic stroke by methods of ozonotherapy, kinesiotherapy, physiotherapy and acupuncture. East European Journal of Neurology. 2017; 6(18): 23-9.

15. Hebert Debbie et al. Canadian stroke best practice recommendations: stroke rehabilitation practice guidelines, update 2015. International Journal of Stroke 11.4 (2016): 459-84.

16. Hertsyk A. SMART goal setting in physical therapy. Фіз. виховання, спорт і культура здоров'я у суч. сусп.: зб. наук. пр. 2016; 2(34): 57-116. 
17. Kernan WN et al. Guidelines for the Prevention of Stroke in Patients With Stroke and Transient Ischemic Attack: A Guideline for Health care Professionals From the American Heart Association / American Stroke Association. Stroke. 2014; 45(7): 2160-236. doi:10.1161/str.0000000000000024

18. Mountain A. et al. Canadian Stroke Best Practice Recommendations: Rehabilitation, Recovery, and Community Participation following Stroke. Part Two: Transitions and Community Participation Following Stroke. International Journal of Stroke. 2020. 174749301989784. doi:10.1177/1747493019897847

19. Powers WJ, et al. Guidelines for the Early Management of Patients With Acute Ischemic Stroke: A Guideline for Healthcare Professionals From the American Heart Association / American Stroke Association. Stroke. 2018; 49(3): 46-99. doi:10.1161/str.0000000000000158

20. Teasell R. et al. Canadian Stroke Best Practice Recommendations: Rehabilitation, Recovery, and Community Participation following Stroke. Part One: Rehabilitation and Recovery Following Stroke; 6th Edition Update 2019. International Journal of Stroke. 2020. 174749301989784. doi:10.1177/1747493019897843

21. VA/DoD Clinical practice guideline for the management of stroke rehabilitation. 2019. Available from: https:// www.healthquality.va.gov/guidelines/Rehab/stroke/VADoDStrokeRehabCPGFinal8292019.pdf

22. WHO methods and data sources for global causes of death 2000-2016. Global Health Estimates Technical Paper WHO/HIS/IER/GHE/2018.3. Geneva: World Health Organization; 2018. Available at http://www.who.int/ healthinfo/global_burden_disease/GlobalCOD_method_2000_2016.pdf].

\section{Literature}

1. Vinychuk SM, Fartushna OI. Early rehabilitation after acute ischemic disorders of cerebral circulation Mizhnarodnyi nevrolohichnyi zhurnal. 2016; 8: 34-9.

2. Ivanska OV, Kalashnik IK. Physical therapy as a means of recovery of patients with ischemic stroke. Visnyk Zaporizkoho natsionalnoho universytetu. 2017; 2: 42-6.

3. Klapchuk VV, Myrenko AO, Ponomariov DA. Comprehensive physical rehabilitation of the elderly in the early stages after stroke. Sportyvna medytsyna i fizychna reabilitatsiia. 2019; 1: 113-8.

4. International classification of functioning, limitations of vital activity and health: ICF. World Health Organization, 2001. 342 p.

5. International classification of functioning, limitations of vital activity and health: IFF, short version. World Health Organization. Saint Petersburg. 2003. 228 p.

6. Mytskan BM. Stroke: types, risk factors, physical rehabilitation. Fizvykhovannia, sport i kultura zdorovia u suchasnomu suspilstvi. 2012; 3(19): 295-302.

7. Molchanova EE. Experience of combined use of dynamic electrical stimulation and acupuncture in the acute period of ischemic stroke. ConsiliumMedicum. 2017; 19(2-1): 82-85.

8. Order of the Ministry of Health of Ukraine 17.04.2014 № 275 Unified clinical protocol of emergency, primary, secondary (specialized), tertiary (highly specialized) medical care and medical rehabilitation. Hemorrhagic stroke (intracerebral hematoma, aneurysmal subarachnoid hemorrhage).

9. Oleynik IV. The state and prospects of stroke management, their socio-medical consequences (literature review). Visnyk morfolohii. 2010; 16(3): 734-7.

10. Khudetskyi II, Khomenko IS, Antonova-Rafi IV. Features of physical rehabilitation of elderly people with neurological diseases. Molodyi vchenyi. 2018; 10 (1): 155-7.

11. lukhymchuk HV. Rehabilitation of stroke patients. Medsestrynstvo. 2018; 3: 23-6.

12. Belagaje Samir R. Stroke rehabilitation. Continuum: Life long Learning in Neurology 23.1, CerebrovascularDisease. 2017. 238-53.

13. Clinical Guidelines for Stroke Management 2017. Available from: https://informme.org.au/en/Guidelines/ Clinical-Guidelines-for-Stroke-Management-2017.

14. Dovguy I, Svyrydova N. Rehabilitation of patients who suffered an ischemic stroke by methods of ozonotherapy, kinesiotherapy, physiotherapy and acupuncture. East European Journal of Neurology. 2017; 6(18): 23-9.

15. Hebert Debbie et al. Canadian stroke best practice recommendations: stroke rehabilitation practice guidelines, update 2015. International Journal of Stroke 11.4 (2016): 459-84.

16. Hertsyk A. SMART goal setting in physical therapy. Фіз. виховання, спорт і культура здоров'я у суч. сусп.: зб. наук. пр. 2016; 2(34): 57-116.

17. Kernan WN et al. Guidelines for the Prevention of Stroke in Patients With Stroke and Transient Ischemic Attack: A Guideline for Health care Professionals From the American Heart Association / American Stroke Association. Stroke. 2014; 45(7): 2160-236. doi:10.1161/str.0000000000000024

18. Mountain A. et al. Canadian Stroke Best Practice Recommendations: Rehabilitation, Recovery, and Community Participation following Stroke. Part Two: Transitions and Community Participation Following Stroke. International Journal of Stroke. 2020. 174749301989784. doi:10.1177/1747493019897847

19. Powers WJ, et al. Guidelines for the Early Management of Patients With Acute Ischemic Stroke: A Guideline for Healthcare Professionals From the American Heart Association / American Stroke Association. Stroke. 2018; 49(3): 46-99. doi:10.1161/str.0000000000000158 
20. Teasell R. et al. Canadian Stroke Best Practice Recommendations: Rehabilitation, Recovery, and Community Participation following Stroke. Part One: Rehabilitation and Recovery Following Stroke; 6th Edition Update 2019. International Journal of Stroke. 2020. 174749301989784. doi:10.1177/1747493019897843

21. VA/DoD Clinical practice guideline for the management of stroke rehabilitation. 2019. Available from: https:// www.healthquality.va.gov/guidelines/Rehab/stroke/VADoDStrokeRehabCPGFinal8292019.pdf

22. WHO methods and data sources for global causes of death 2000-2016. Global Health Estimates Technical Paper WHO/HIS/IER/GHE/2018.3. Geneva: World Health Organization; 2018. Available at http://www.who.int/ healthinfo/global_burden_disease/GlobalCOD_method_2000_2016.pdf].

\section{Інформація про авторів}

Сибірякін Ярослав Вадимович

https://orcid.org/ /0000-0002-5758-1577

yaroslav.sibiryakin@gmail.com

380970383021

Балаж Марія Степанівна,

https://orcid.org/ /0000-0002-6710-9567

balazhms@gmail.com

Національний університет

фрізичного виховання і спорту України,

03150, Київ, вул. Фізкультури, 1

\section{Information about the authors}

Sybiriakin Yaroslav https://orcid.org/ /0000-0002-5758-1577

yaroslav.sibiryakin@gmail.com 380970383021

Balazh Mariia https://orcid.org/ /0000-0002-6710-9567 balazhms@gmail.com

National University of Ukraine on Physical Education and Sport, 03150, Kyiv, Fizkul'tury str., 1. 